\title{
The Philosophy of "Fasting" in Terms of Holy Quran and Medicine
}

\author{
Ahmad DN and Mohammad RA* \\ $\mathrm{PhD}$ in Comparative religions and Mysticism, Iran
}

*Corresponding author: Mohammad reza Afroogh, Azad University, Iran, Tel:

Conceptual Paper

Volume 2 Issue 2

Received Date: May 25, 2019

Published Date: June 13, 2019

DOI: $10.23880 /$ phij-16000119

\section{Abstract}

The relationship between religion and science is unbreakable. It is because the Almighty God creates it. So with the creation of the existence, the emergence and occurrence of science along with religion is also necessary. So both religion and science are two truths that lead to the creation of the existence. Religious theology, which is explained in the language of the divine, with the natural and cosmic theology, which is expressed in the language of the scholars, is both accepted and prevalent.

Here we are going to coordinate the religious and scientific views on the cause and philosophy of existence and the necessity of fasting. Fasting is important not only for the health and well-being of the human body, but also for the health of the soul. Because man is a three dimensional being, having the dimension of the soul, the body and the mind, and all three dimensions together, make him meaning.

In this article, the purpose is to emphasize the importance of fasting in terms of physical and mental health. In this research, we try to use a descriptive-analytical method to express the effect of fasting on the physical and mental health of humans.

Keywords: Fasting; Health; Body; Soul; Psyche

\section{Problem Statement}

Fasting among divine religions has a long history and is one of the long-standing devotions that can be derived from the passing away of Adam and Eve from paradise. Some commentators say that God made the fast of the thirteenth, fourteenth, and fifteenth of each month obligated to a person. God says in the Qur'an: "O you who believe, the fast was written to you, as it was written on the people who were before you, hope to be virtuous." (Cow, verse 183); this verse indicates that the fasting of the Muslims and the nations before them was also obligatory. Imam Ali (P.B.U.H) says: "The fasting of old worship is that God has not exempted any nation from it."

The difference in fasting in religions is due to the number of days and how fast it is, although in different religions there is a difference between the details and the quality of fasting, but the principle of the fasting rule is that its purpose is to purify the soul in general and to purify and purify the spiritual and eliminate the suffering.

But what's striking here is that only Muslims, Christians and Jews are not fasting, but even non-divine religions, such as Buddhism and Hinduism, are also 


\section{Philosophy International Journal}

fasting and physical austerities to cultivate the body and spirit of their followers Essential. From the current Torah and the Bible, we realize that fasting existed among the Jews and Christians, and other nations and nations were fasting when faced with sorrow and grief. In the Bible, it reads: "Fasting has always been common among all tribes and nations and religions in times of grief and uneasy labor." It is also clear from the Torah that Moses was fasting for forty days. It is: "When I come to the mountain, I take the stone tablets, that is, the tablets of the covenant which God has with you. Then I stayed on the mountain forty days and forty nights; I did not eat bread or drink water. "It is also apparent from the Luke's gospel that the apostles of Christ also fasted. In this research, we try to answer three important questions about fasting.

1. Is fasting recommended in pre-Islamic religions?

2. Do science of medicine and Quran agree on the benefits of fasting?

3. Is fasting effective in strengthening mental health and human spirit?

\section{Introduction}

The most important effect of fasting is its educational aspect. The fast makes the human soul subtle and the human will also become strong and moderates its instincts.

Everyone believes in the central role of fasting in selfperfection and self-perfection, from the forefathers who refrain from specific refrains from the purification of the soul, to the Sufis who are afraid and the fast is their principles, and the mystics who say: "It is empty of food, so that in him the light of knowledge of the nose." It is because fasting is a practice of resistance and a spiritual readiness in self-development.

Fasting, in spite of the hunger and thirst of food and water, should also take an eye out of some pleasures, and practically prove that it is not like an animal in the stables and grass. He can take control of the rogue affairs of the soul and through tireless and tireless exercises to overcome the temptations of the abdomen and lust and dominate his lusts.

In fact, the greatest philosophy of fasting is its educational and spiritual effect. A person who has a variety of foods and drinks and who comes to it whenever hungry and thirsty, is like trees that grow on the banks of the streams in the garden's walls, these creepy trees are very weak and Are running low. If one day the water is cut off from their feet, they will wither and dry; but the trees that climb in the mountains and deserts along the rocks, and at the same time grow, always with storms Hard, sunburn, cold winter, and with all kinds of deprivation, are very sturdy and durable. Fasting separates man from the animal world and takes the world of angels.

The prophet of Islam (P.B.U.H) says: "fasting is against the fire of hell"-Tabatabai, Mohammad Hussein (2006, p. 2 , p. 191) means fasting and the forgiveness of sins and suffering of man, which is achieved by the fast of salvation from the fire of hell and the punishment of the Lord.

Fasting will revive the spirit of virtue, and this fruitful care during Ramadan and fasting is much easier because hunger and thirst and other fasting limits of the rogue flames of animal instincts and desires It turns out to be extremely silent, and even if it is temporary, it leaves the wisdom and soul out of the clutches of passion, and for fasting, it is prepared to practice piety and piety, and through care and practice in succession in one The moon has a deterrent effect of guilty, and its routine and routine grows, and he succeeds in completing this one month program. From the day of the famine, he will remain alert. In this way, you must fast in fasting, in spite of the hunger and thirst of food and water, and enjoy some pleasures, and actually prove that it is not like an animal in the stables and grass. He can take control of the rogue affairs of the soul and through tireless and tireless exercises to overcome the temptations of the abdomen and lust and dominate his lusts.

\section{Psychological effects of fasting}

\section{Role of fasting in strengthening will}

A man with fasting, who is willing to eat and drink and refrain from some other things, actually fights his wishes and resists his instincts, practicing this action, determination and determination in a powerful person, and makes life from the rule of government and the domination of desires and desires. The leaders of Islam have said: The best people are the one who is fighting with the air, and the strongest is the one who will win it. So, fasting is the best man in the world because it fights with the sensual demands, and if they can take control of their fasting with their fasting, they will be among the strongest people -Yasin, Verses (183 and 43).

The fasting person, first of all, by resisting his most powerful natural and instinctive demands of eating and drinking, etc., strengthens his will and strengthens his most important habits and leaves his breath away. It governs itself independently. The famine of the soul and of the human being cleanses and cleanses man from 


\section{Philosophy International Journal}

unsatisfied pleasures and brings out the reins because when the human abdomen is empty of food. Piety, trust, honesty and summary of his humanity are strengthened and the light of faith manifests itself in his heart.

Prophet Jesus, son of Maryam (P.B.U.H) said: "Keep your belly, empty, perhaps you see your Lord through the heart"-Hadrami, Salem (2005, p. 1, p. 180).

\section{Fasting and patience}

"Patience" is one of the characteristics that has been emphasized in Islamic ethics, a Muslim man faces his own problems in his personal and social life. Without the character of patience, it is not easy to win problems and achieve goals. Patience and resistance increase man's sustainability and empower his will. No society if it does not tolerate mischief, cannot overcome various problems and its enemies. With patience and resistance, it is possible to fight the oppressors, to shorten the hands of the colonizers, and fasting - especially in the warm and long days of the summer when the strain of thirst is exhausting, dramatically worsens and resists mankind. It makes it easy for people to endure pain and suffering.

According to this work, the Holy Quran has interpreted fasting for patience, and says: "0 you who believe, there is patience and prayer for you. (Repentance, verse 112) Also, our infallible Imams (P.B.U.H) have interpreted "patience" in this verse for fasting. The Holy Prophet (P.B.U.H) also called Ramadan for the month of patience: Ramadan is the month of patience and the reward is the patience of heaven.

\section{Fasting and Contentment}

Unlike the material schools of the East and the West, the world believes that the world and its material blessings are the means for spiritual development and the achievement of eternal prosperity. Therefore, Islamic culture is not a culture of enjoyment and consumption, but a culture of contentment and self-sacrifice. In material methods, man's tone and sleep are authentic, and greed is more for human suffering, and in Islam, originality is with human spirituality, and sacrifice and sacrifice are the means of achieving a far higher level of humanity.

Fasting is a testament that forbids Muslims from indulging in materialism and greed for material pleasures and races for consumption and education, and teaches them to be in the minds of others, and upon request Being fluent in his body and consuming it with the amount of need, and avoiding wastefulness. Fasting teaches Muslims that life and greed can only be drowned in materiality and deviated from spirituality, and it is not necessary to live with all the being and pleasures.

Fasting is a testament that forbids Muslims from indulging in materialism and greed for material pleasures and races for consumption and education, and teaches them to be in the minds of others, and upon request Being fluent in his body and consuming it with the amount of need, and avoiding wastefulness. Fasting teaches Muslims that life and greed can only be drowned in materiality and deviated from spirituality, and it is not necessary to live with all the being and pleasures.

\section{The Moral Effects of Fasting}

The class system and the gap between the poor and the morphine are one of the reasons for dissatisfaction in the system and society. Depending on the degree of class divide, social anomalies and moral corruption increase, and the poor group, through economic pressures and social deprivations, becomes envious and vindicated to the wealthy than they are which a work of social violence is.

Based on the principle of "social justice," the Islamic law of Islam, based on the utmost effort, regulates the relations of society, and since human nature is diverse due to its individual talents and abilities, it has always been trying to By forging various sentences and decrees, it also minimizes the natural difference, including these sentences, "fasting" which creates the conditions for the rich to understand and diminish the perceived position of the disadvantaged, their economic pressures and their social suffering, and thereby eliminate society from distress and dissatisfaction and create the spirit of fraternity and convergence they create them. When Hisham ibn Hakam asked from Imam Sadegh (P.B.U.H) for the philosophy of fasting, Imam Sadegh (P.B.U.H) says: "Indeed, God obliged fasting to equalize between the poor and the rich" (Verse 12).

\section{Health Effects of Fasting}

Fasting, in addition to educational and social benefits, also has health benefits. Fasting freezes all body devices from constant fatigue, prolongs life, gives a new body of joy and brings people out of boredom, frees up sickness and pain and eliminates excessive obesity.

Fasting results in the removal of specific glycogen or fat deposits from different parts of the body and reaching internal metabolism and it is certain that the fasting body first consumes subcutaneous fat and gradually turns into 


\section{Philosophy International Journal}

fat Viscous Doctor Alexis Carl writes in "Human, an Unknown Person": "You fast, with fasting blood glucose in the liver and the fat stored under the skin and muscle and endocrine proteins and Liver cells are released and consumed by nutrition."

"The necessity of fasting is emphasized in all religions," he says. At fasting, hunger and sometimes a nervous stimulation and weakness are felt first, but at the same time, the quality qualities that are important are and finally, all members sacrifice their own materials to maintain and balance the inner environment and the heart, thus fasting and rejuvenating all body tissues."

Dr. Jean Furusan interprets the treatment of fasting with the condition of the body, which at the beginning of fasting is the language of pregnancy, the sweat is a lot of body, the mouth is stinky, and sometimes water flows from the nose, all of which marks the beginning of the body's full throat. After three to four days, the odor is eliminated, the uric acid is reduced, and the person feels like extraordinary lightness and joy. However, members have enough rest.

Dear religious leaders, in the Islamic narrations and prayers of the month of Ramadan, they called the month of equality. Out of the obvious results of fasting, it provokes a sense of sympathy for poor people and those who are not well-off, those who have a comfortable life without suffering from poverty and hunger, may be unaware of the needy, and fasting is a means that $\mathrm{He}$ neglects and remembers the suffering of the poor, so that they will help the poor to arrest and reach their hearts.

Dr. Toomanas writes about the benefits of fasting: "The great benefit of eating and avoiding foods in a short time is because, since the stomach was full of food during the course of eleven months, during a month's fasting You will get rid of your food, and the liver that has to constantly consume bile for digestion will spend bile secretions for thirty days to dissolve the remaining amount of accumulated food. Eating food will lead to a slight amount of leisure and relieve fatigue. Fasting is a lack of eating and drinking for a specified period of time, and this is the best way to heal and maintain well-being. Because of the old and new medicine, it has been developed for this purpose, especially when it affects the digestive system, especially the kidneys and the liver, and cannot be treated by medication, fasting is well treated. The best medicine for the relief of indigestion is also fasting, which is a liver disease that causes jaundice. The best way to treat it is to fast, because the disease is often caused by liver fatigue, which does not function during much of it. It can take bile."

"Four fifths of the disease results from fermentation of food in the intestines, which is all corrected by fasting," says Dr. French Guelle.

Doctor Alex Soufrin writes: "The body consumes and retains the substance at fasting instead of food, and thus the dirty and infectious material that is present in the body and the root of the disease It is destroyed, fasting is the remission of all diseases, so it is desirable to cleanse your body by fasting."

"Every sick person should avoid food in a year because, as the food reaches, germs are growing, but when it comes out of food, germs going to the weak."

"The fasting that has been become obligatory by Islam is the biggest guarantor of health," he added.

Fasting helps to improve the complications of some diseases, such as:

1. When the stomach and intestinal insufficiency, the patient suffers from severe pain.

2. When weight gain increases due to overeating and low exercise.

3. In patients with hypertension.

4. In diabetes.

The Great Prophet of Islam, Prophet Muhammad (P.B.U.H) centuries ago, said this in a profound saying: the stomach is the house of all pain and disease and the best way of curing is fasting. (Fakhr Razi, 1387, p. 15, p. 68)

\section{Conclusion}

The science of medicine and the holy Quran emphasize the direct impact of fasting on the body and human life. Prophet Muhammad (P.B.U.H) said: try to fast in order to be health. Medicine also tells us: The best way to get rid of harmful substances is through the body of fasting. Therefore, according to what was said, the following results were obtained about fasting and its effects.

1. The spiritual effect of fasting on the human soul is very high.

2. Fasting strengthens the human will and strength.

3. Fasting has an important impact on strengthening our emotional aspects such as virtue and virtue.

4. Fasts detoxify poisons and pests.

5. Fasting gives body cells the opportunity to rest.

6. Fasting causes the kidneys and the urinary tract to rest.

7. Fasting reduces fat deposits in the veins and prevents atherosclerosis. 


\section{Philosophy International Journal}

8. Fasting is the best way to treat hunger, which Europeans consider to be very important.

9. Benefit of fasting is better than medication.

10. Fasting is the gift of God to humans and prophets.

11. Fasting is a worship for being close to God.

12. Our fast protects the fire of hell.

\section{References}

1. The Holy Quran

2. Nahj al-Balaghah (Imam Ali's sayings (P.B.U.H))

3. Bible (Old and New Testament)

4. Ahmad, The Philosophy of Executions, Islamic Printing Press, Isfahan, 1344 AH

5. Amin Shirazi, Ahmad, Islam Dr Bidar, Islamic Publications Office. $8^{\text {th }}$ (Edn.), $1373 \mathrm{AH}$

6. Cheraghi A (1999) Medicine in the Qur'an, Mntibi Beyat Publishing.

7. Ebne Babevey (2000) Oyon Akhbaro Reza (P.B.U.H), Islamic pub, Qum.

8. Hakim, Seyyed Mohammad Baqir, Al-Qur'an Science, 1417.H
9. Hick J (1993) Philosophy of Religion. Hoda International Publishing House, Tehran.

10. (2014) Javadi Amoli, Abdollah, Mafatihol Hayat, Islamic pub, Qum.

11. Nor, Ayatollah Hossein, Space Age Knowledge, Morteza Publishing House, Qom, 1370 AH.

12. Majlesi MB (2006) Biar al-Anwar, Islamic School, Tehran.

13. Makarem Shirazi, Nasser, Sample Commentary, Darul Kabul Eslamyyeh, Tehran, $1373 \mathrm{AH}$

14. Motaghi hendi A (2011) Kanz ol omal, Osvah pub, Qum.

15. Rey S, Mohammad M, Amir al-Hekmeh, Islamic Propagation Office, Qom, $3^{\text {rd }}$ (Edn) 1367 AH.

16. Rezaei I, Mohammad Ali, Coming to the Scientific Interpretation of the Quran, Oswah Publications, Qom, $1365 \mathrm{AH}$.

17. Tabari, Abi Ali al-Fadl, Interpretation of the Assembly of Al-Bayan, School of Islam, Tehran, $1395 \mathrm{AH}$. 